\title{
Global Peace Initiative: The Expedition of Philosophic Knowledge
}

\author{
Olisaemeka Raphael Maduabuchi, Ph.D(Nig) \\ Department Of Philosophy, chukwuemeka Odumegwu Ojukwu University, igbariam Campus, Anambra State, \\ Nigeria \\ Arts, Humanities \& Global Peace Initiative In $21^{\text {st }}$ Century \\ Philosophy And Global Peace Initiative In The $21^{\text {st }}$ Century
}

\begin{abstract}
This paper sought to examine philosophic knowledge as the expedition of global peace initiative in the $21^{\text {st }}$ century. Social contract is established for Man to live in peace with others in the society. But, so many factors are militating against the peaceful co-existence of people in this $21^{\text {st }}$ century world. This paper posited that philosophy is the fountain of knowledge that provides ethical guidelines necessary to promote global peace initiative. Hence, ideas emanating from philosophic knowledge can initiate change in people's set of mind. Peaceful co-existence among people and nations in this $21^{\text {st }}$ century is essential for development and propagation of human species.
\end{abstract}

Key words: Global, peace, philosophy, knowledge, initiative, ethical and guideline

\section{INTRODUCTION}

Peace is essential in this $21^{\text {st }}$ century world for the survival of humanity. In today's polarized world, several factors are responsible for social division, antagonism, conflict and war. It is unfortunate that the whole world is suffering from problems emanating from terrorism, communal and ethnic riots, racial discrimination, ideological extremism, religious intolerance, party-politics, social injustice, denial of human rights, unemployment and so on. ${ }^{1}$ Global Peace is threatened by international, ethnic and civil wars experienced in many parts of the world. Today, war has created enmity between countries. The effect has resulted to death, destruction of properties and environmental degradation. Sometimes, peace is conceived in the negative as absence of war. The devastating effect of war has necessitated that peace is important for propagation of human species. Global peace initiative is endemic in this $21^{\text {st }}$ century world from all works of academic disciplines Philosophical enterprise has expounded ethical guidelines, which is necessary to promote global peace initiative in this modern era. Hence, philosophy is a positive ideology that brings change in people mode of thought. Those ideologies that divide and exploit humanity stand in need of change in order to promote global peace, mutual love and social welfare. At this point, it is important to clarify the key concepts that are associated with this work.

\section{CONCEPTUAL CLARIFICATION OF BASIC TERMS}

The two basic concepts in this study are: peace and philosophic knowledge. There are different dimensions of peace. Peace is can be conceived both in positive and negative terms. The positive aspect of peace is the inner state of calm or tranquility, which is attained through the inculcation of good virtues like friendliness, compassion, mercy, moderation, modesty, forgiveness, non-violence, love and so on. ${ }^{2}$ Personal peace leads to social peace, which has to do with inter-personal social relations, social justice and development. At state or national level, peace can be conceived as a state of stability, progress and freedom from civil disorder.

On the other hand, peace in the negative terms connotes absence of war. It is associated with pacifism. As a term, pacifism is derived from two Latin words 'pax' meaning 'peace' and 'ficus' meaning 'making'. So, pacifism from the root meaning means peacemaking. It is a commitment to peace and non violence. ${ }^{3}$ Peace is attained by eliminations of war. At international level, it calls for peaceful relation among all nations of the earth. In other words, pacifism is linked with global peace. Global peace is peaceful co-existence of all existent. In line with this view point, word peace is an ideal state of freedom, peace and happiness among and within all nations and peoples.

Another important concept that is associated with this work is philosophic knowledge. Philosophic knowledge is a rational or inferential knowledge that is attained through the exercise of pure reason. Logic is the 
tool of operation of philosophy. Apart from the fact that philosophy is an intellectual discipline, philosophy is any kind of wisdom or set of principle that guides and gives meaning to human life. Philosophy provides the ethical principle or rationale for global peace initiative in this contemporary era. Normative values elucidated by ethics promote and guide human conducts in the society towards attaining global peace in the $21^{\text {st }}$ century world. It is good at the point to look at how philosophy can promote global peace initiative in the $21^{\text {st }}$ century.

\section{PHILOSOPHY AND GLOBAL PEACE INITIATIVE}

Down through the ages, philosophical ideologies or mindsets are the driving force for peace and war. Philosophy is not just an academic venture; it is an approach, outlook and way of life. Unfortunately, philosophical ideologies expounded by Heraclitus, Hegel and Marx amidst others conceive conflict or strife as a necessary condition for progress. Such ideology is the motivating factor behind wars witnessed in history. The use of sophiscated weapons of mass destruction threatens the survival of both human species and ecological factor of the natural environment.

On the other hand, global peace is an ethical prerogative for the survival of humanity and its natural environment. Philosophy serves to re-orient the citizens of the global village to reconsider those negative orientations that exploit and divide humanity. For peace to reign in the world, communities and nations stand in need of change of heart. No wonder, B. O. Eboh observed that the deepest roots of the oppression and tension that militates against peace and development are to be found in human heart. ${ }^{4}$ Thus, the change must start with individual because national transformation starts with conversion of individuals.

The ideology that conflict or strife is an essential condition for progress must be changed with peace. Peace is a favourable condition for progress and development in any human society. It connotes respect for others, justice and equity among individuals and nations. This 21 st century world has been marred by terrorism, racial discrimination, religious intolerance, and other ills. However, Emmanuel Levinas conceived ethics as the first philosophy. ${ }^{5}$ Hence, philosophy has expounded several ethical theories and guidelines that can advance peace in this modern world.

Some ethical theories provide the rationale for peace. For instance, Stoic ethics postulated that all men are brothers and citizens of the world. ${ }^{6}$ Peace and mutual co-existence among people and nations in this $21^{\text {st }}$ century world will be attained when people see themselves as brothers and fellow citizens of the earth. There will be no room for oppression, slavery, racial discrimination and other ills in the society. Thus, the relationship among people and nations in this $21^{\text {st }}$ century should be geared towards satisfying the primary needs of humanity. In this regard, the advanced economies of the world should assist the developing countries so that everybody will enjoy the good fruit of the earth.

It was philosopher Francis Bacon who postulated that knowledge is power. The knowledge expounded by philosophy has proffered several solutions towards resolving conflicts and violence in the present day world. As the oldest academic discipline, every field of study took its root in philosophy. Peaceful co-existence among people and nation is a noble ideal. A German Jewish philosopher Martin Buber postulated the ideal human relation that characterizes human relation in his philosophy of 'I-Thou'. 'I-Thou' relation is the mutual interpersonal human relation that respects the humanity of individuals. It synchronizes with Kant's categorical imperative, which is a universal maxim that regards and treats human beings as an end-in-itself. ${ }^{7}$ Thus, treating your fellow human beings as a means to an end amounts to reducing the humanity of individuals to object, which gives room for injustice, anarchy, violence, terror, war, conflict and other atrocities in the society. Today the whole is engrossed in opposition, conflict and antagonism, which threatens the peace co-existence of people and nations in this modern world.

\section{FACTORS MILITATING AGAINST GLOBAL PEACE INITIATIVE}

One of the main factors militating against global peace in this modern era is religion. Religious intolerance has constituted a great threat to peaceful co-existence among people and nations in the $21^{\text {st }}$ century. Religion that promotes violence and sees those outside its sect as infidels to be exterminated has been the main cause of social disturbance in human society right from time immemorial. This is an alteration of the 'true' significance of religion. Religion when properly followed promotes peace, harmony, goodwill, and social cohesion.

Another factor that can militate against the peaceful co-existence of people and nations is jealousy. Being jealous of others' prosperity has constituted the internal object of hatred between two groups of people, religions, communities, nations, countries, races and so on. ${ }^{9}$ Education promotes emotional maturity to identify with people's success and progress. Mutual co-operation among people and nations in this $21^{\text {st }}$ century is indispensable for peace and development in this modern world.

In addition to this, injustice has constituted an object of many controversies in this modern world. Hence, T. Okere observes thus: 
Individuals have engaged in bloody duels, families in bitter vendettas in the name of justice. Nations have gone to war in pursuit of justice, while their peace is almost invariably a function of the degree of justice inside and outside their borders. ${ }^{10}$

Injustice is a canker worn that has eaten deep into the marrow of this present society. Justice is the ideal virtue cherished by all. It is a fair treatment of all citizens. Peace will reign when this is justice in the society. In this regard, justice requires equation in human affairs in terms of sharing of resources, contracts, rights, privileges and benefits in the society. According to B. O. Eboh, justice is a necessary virtue of individuals in their interaction with others and the principal virtue of social institution. ${ }^{11}$ There will be peace in the world when the relationship among people and nations is guided by justice and fair-play.

\section{EVALUATION}

Peace is not a natural endowment. The natural state of mankind prior to emergence of civil society is not peaceful. It is a state of war of all against all. There is no pre-established law-governed harmony. Hence, everybody has to defend his own right with one's own private sword before a civil condition is established. All people and nations in this $21^{\text {st }}$ century must work for global peace. Kant proposed that States have to give up their externally lawless freedom in the external relations among States in order to accord with one another. ${ }^{12}$

On the other hand, war is conceived as a true instrument of peace. There is a dictum, which says that 'If $\mathrm{u}$ want peace prepare for war'. In international relation where there is antagonism and competition, the will of strongest prevails. Peace in this regard is the fear of the other. Such a peace is not the ideal but a reflection of cold war. Nonetheless, global peace must be built on the principle of mutual dialogue and solidarity in the society.

\section{CONCLUSION}

This paper has looked at global peace initiative as the expedition of philosophic knowledge. Philosophic knowledge has expounded ethical principles require to enhance global peace in this $21^{\text {st }}$ century. Global peace is a necessary condition for human progress and survival in the society. It is a moral duty on part of every citizens of this global village to work together to abolish wars for the purpose of ensuring peace in this modern world.

\section{REFERENCES}

[1] Chhay Rai, Rani Durgawati Vishwa, Jabalpur Vidyalaya, and Madhya Pradesh, Moral Philosophy of Global Ethics, http://www.bu.edu/wcp/MainValu.htm, Retrieved on 07-11-16

[2] Andrew Fiala, "Pacifism" in Stanford Encyclopedia of Philosophy (Winter 2014 Edition), Edward N. Zalta (ed.), http:// plato.stanford.edu/archives/win2014/entries/pacifism/>, Retrieved on 07-11-16

[3] Wikipedia Contributors, World Peace in Wikipedia, The Free Encyclopedia, http://en.wikipedia.org/w/index.php?title=World_peace\&oldid=742812080, Retrieved on 05-10-16

[4] Ben Okwu Eboh, Living Issues in Ethics, (Nsukka: Afro-Orbis Publishing Co, 2005), 116-117

[5] Sean Hand ed., The Levinas Reader: Emmanuel Levinas, (Oxford: Basil Blackwell Ltd, 1989), 75-87

[6] Joseph I. Omoregbe, Ethics: A Systematic and Historical Study, (Ikeja: Joja Educational Research and Publisher Limited, 1993), 71-80

[7] Raphael Olisa Maduabuchi, Epistemological Orientation of Martin Buber's 'I-Thou': A Panacea to Global Reconciliation in the $21^{\text {st }}$ Century, ANSU Journal of Arts and Humanities, July 2015, 2(2): 231236

[8] Devinder Singh. Chahal, Nanakian Philosophy and World Peace, A paper presented at conference of Universal Peace Declaration, http://www.upf.org, Retrieved on 05-10-16

[9] Joseph O. Eneh, War \& Peace: Aspect of Practical Ethics, Calabar: Afranedoh Nig. Ltd, 2001, p.111

[10] Theophilus Okere, Culture and Religion, Owerri: Blank Academic Press, 1974), 60

[11] Ben Okwu Eboh, Living Issues in Ethics, 103

[12] Immanuel Kant, Perpetual Peace: A Philosophical Sketch, http://www.mtholyoke.edu/acad/intrel/feroespghtm, Retrieved on 05-10-16 